\title{
Investigations of a CA repeat in the oestrogen receptor $\beta$ gene in patients with Alzheimer's disease
}

\author{
Charlotte Forsell ${ }^{*, 1}$, Eva Enmark ${ }^{2}$, Karin Axelman ${ }^{1}$, Mari Blomberg ${ }^{1}$, Lars-Olof Wahlund ${ }^{1}$, \\ Jan-Åke Gustafsson ${ }^{2}$ and Lars Lannfelt ${ }^{1}$
}

\author{
${ }^{1}$ Department of Geriatric Medicine, Karolinska Institutet, NEUROTEC, Novum, KFC, S-141 86 Stockholm, Sweden; \\ ${ }^{2}$ Center for Biotechnology and Department of Medical Nutrition, Novum, S-141 57 Stockholm, Sweden
}

Several studies have shown that oestrogen treatment after menopause decreases the risk for Alzheimer's disease (AD). It is also known that oestrogen stimulates the outgrowth of nerve cells and that apolipoprotein E (Apo E) synthesis and amyloid precursor protein (APP) metabolism are regulated by oestrogen. Recently a new oestrogen receptor was identified, oestrogen receptor $\beta(\operatorname{ER} \beta)$, located at chromosome 14q22-24.

Several genes close to this chromosomal region have been implicated in AD, but the results are conflicting. Our hypothesis was that variations in the $\operatorname{ER} \beta$ gene could be the underlying cause to the positive findings in these genes and we have therefore investigated a CA repeat ${ }^{1}$ in intron 5 of the $\operatorname{ER} \beta$ gene. Three hundred and thirty-six $A D$ cases and $\mathbf{1 1 0}$ healthy age-matched controls were included in this study. Fourteen different alleles were found with frequencies between 0.1 and $37 \%$. There was no significant difference between AD cases and controls when all alleles were compared. However, allele 5 was seen in $13.6 \%$ of the controls but only in $8.0 \%$ of $A D$ cases $(P=0.014$; odds ratio $(O R)=0.55)$. No $A D$ patient homozygous for this allele was seen but three controls were homozygous. In conclusion, our findings suggest the ER $\beta$ allele 5 to be a protective factor. However, this has to be confirmed in a larger population. European Journal of Human Genetics (2001) 9, $802-804$.

Keywords: Alzheimer's disease; oestrogen receptor $\beta$; chromosome 14; gene; dementia; ER $\beta$

\begin{abstract}
Introduction
Epidemiological studies have shown that women have a higher risk of developing $\mathrm{AD}$ than men, ${ }^{2,3}$ and several studies indicate that oestrogen improves memory ${ }^{4}$ and that oestrogen replacement therapy may delay the onset of $\mathrm{AD}$ in postmenopausal women. ${ }^{5-7}$ However, large placebo-controlled trials and well-designed epidemiological studies are required to address the role of oestrogens in prevention and treatment of $\mathrm{AD}$ as there have also been negative studies. ${ }^{8}$ Oestrogen has been reported to increase the non-amyloidogenic processing of $\mathrm{APP},{ }^{9}$ up-regulate the Apolipoprotein E gene (APOE) expression, ${ }^{10}$ improve cerebral blood flow, ${ }^{11}$
\end{abstract}

*Correspondence: Charlotte Forsell, Department of Geriatric Medicine, Karolinska Institutet, NEUROTEC, Novum, KFC, S-141 86 Stockholm, Sweden. Tel: +46 8585864 72; Fax: +46 8585838 80;

E-mail: charlotte.forsell@neurotec.ki.se

Received 19 April 2001; revised 10 July 2001; accepted 30 July 2001 facilitate neuronal repair, reduce neuronal injury and stimulate glucose transport and metabolism. ${ }^{12}$ An association to $\mathrm{AD}$ has been reported for the oestrogen receptor $\alpha$ $(\mathrm{ER} \alpha)$ gene in several studies ${ }^{13,14}$ but there has also been a negative report. ${ }^{15}$ Recently, a new oestrogen receptor was identified, oestrogen receptor $\beta(\operatorname{ER} \beta)^{16,17}$ located at chromosome $14 \mathrm{q} 22-24 .^{18} \mathrm{ER} \alpha$ and $\mathrm{ER} \beta$ mRNA have been localised in the pyramidal cells of the rat hippocampus and $\mathrm{ER} \beta$ mRNA in rat cortex, ${ }^{19}$ indicating that oestrogen may directly modulate the structure and function of these neurons. Other genes that have been implicated as genetic risk factors for AD are $\alpha 1$ antichymotrypsin, dihydrolipoyl succinyltransferase (DLST) and a polymorphism in intron 8 of presenilin 1, all located at chromosome 14q22-32. However, it has not been possible to clearly link any of these genetic risk factors to the disease, as research groups have conflicting results. To evaluate if variations in $\mathrm{ER} \beta$, localised to the same chromosomal region, could explain the discrepancy observed for the genes at 
chromosome $14 q 22-32$, we have investigated a CA repeat ${ }^{1}$ in intron 5 of the $\mathrm{ER} \beta$ gene, in $\mathrm{AD}$ patients and healthy controls.

\section{Materials and methods}

The subjects consisted of $336 \mathrm{AD}$ patients (mean age of disease onset $66 \pm 9$ years, mean age $71 \pm 9 ; 214$ women, 122 men) and 110 healthy controls, matched for age and gender (mean age $68 \pm 11$ years; 73 women, 37 men). Patients were selected from families included in the Alzheimer register at the Karolinska Institutet ${ }^{20}$ as well as patients attending the Department of Geriatric Medicine at Huddinge University Hospital. The diagnosis of $\mathrm{AD}$ was established according to the DSM-IV. ${ }^{21}$ Controls were cognitively healthy individuals from two sources. One group was married to AD patients ( $n=83$ ) with whom we have had contact for several years and with no family history of dementia. The other group was from the Swedish Pensioner Society $(n=27)$ that had gone though extensive dementia investigations at the Department of Geriatric Medicine at Huddinge University Hospital. ${ }^{22}$

DNA was prepared from blood using standard procedures. The CA repeat, in intron 5 of the ER $\beta$ gene was amplified with the following primers: 5'-GGT AAA CCA TGG TCT GTA CC-3' and 5'-AAC AAA ATG TTG AAT GAG TGG G-3', of which the latter was labelled with the fluorescent dye 6-Fam. To determine the different alleles the PCR products were analysed on an ABI377 (Applied Biosystems, USA). The frequencies of $\mathrm{ER} \beta$ genotypes were compared using CrossTabulations and standard Chi-square tests. Odds ratios were calculated by logistic regression analysis to estimate the relative risk of developing $\mathrm{AD}$ according to different $\mathrm{ER} \beta$ genotypes. The cumulative contribution of $\operatorname{ER} \beta$ and APOE gene polymorphisms were calculated using univariate analysis of variance. All statistics were computed using SPSS 9.0 for Windows NT (SPSS Inc., USA).

\section{Results and discussion}

Fourteen different alleles (147 - $173 \mathrm{bp}$ in length) were found with frequencies between 0.1 and $37 \%$ (Table 1 ). There was no significant difference between $\mathrm{AD}$ cases and controls when all alleles were compared. However, a significant difference was found between cases and controls when ER $\beta$ allele 5 (155 bp) was studied. ER $\beta$ allele 5 was seen in $13.6 \%$ of the controls but only in $8.0 \%$ of $\mathrm{AD}$ cases $(P=0.014$; $\mathrm{OR}=0.55 ; 95 \% \mathrm{CI}=0.34-0.89)$. No influence of age on $\mathrm{ER} \beta$ allele 5 frequency was seen with logistic regression analysis. Univariate analysis of variance demonstrated independent effects of $\mathrm{ER} \beta$ allele $5(P<0.05)$ and $\mathrm{APOE} \varepsilon 4 \quad(P<0.001)$ genotypes but no cumulative effect $(P=0.675)$. Furthermore, subdividing according to sex, we found a significantly decreased risk for men with the $\mathrm{ER} \beta$ allele $5(P=0.045$; $\mathrm{OR}=0.46 ; 95 \% \mathrm{CI}=0.21-0.99)$ but not for women $(P=0.11)$ (Table 2). This might reflect that men are less prone to develop $\mathrm{AD}$ or that we have not controlled for oestrogen
Table 1 Sizes, number of CA repeats and frequencies of the alleles at the ER $\beta$ locus, in AD cases and controls

\begin{tabular}{lccrrrr}
\hline Alleles & $\begin{array}{c}\text { Sizes } \\
(b p)\end{array}$ & $\begin{array}{c}\text { No. of CA } \\
\text { repeats }\end{array}$ & \multicolumn{1}{c}{$\mathrm{n}$} & $\begin{array}{r}\text { Controls } \\
(\%)\end{array}$ & $\mathrm{n}$ & $(\%)$ \\
\hline 1 & 147 & 14 & 1 & $(0.1)$ & - & - \\
2 & 149 & 15 & 28 & $(4.2)$ & 4 & $(1.8)$ \\
3 & 151 & 16 & 24 & $(3.6)$ & 6 & $(2.7)$ \\
4 & 153 & 17 & 9 & $(1.3)$ & 4 & $(1.8)$ \\
5 & 155 & 18 & 54 & $(8.0)$ & 30 & $(13.6)$ \\
6 & 157 & 19 & 18 & $(2.7)$ & 7 & $(3.2)$ \\
7 & 159 & 20 & 36 & $(5.4)$ & 10 & $(4.5)$ \\
8 & 161 & 21 & 103 & $(15.3)$ & 24 & $(10.9)$ \\
9 & 163 & 22 & 251 & $(37.4)$ & 80 & $(36.4)$ \\
10 & 165 & 23 & 106 & $(15.8)$ & 38 & $(17.3)$ \\
11 & 167 & 24 & 20 & $(3.0)$ & 8 & $(3.6)$ \\
12 & 169 & 25 & 17 & $(2.5)$ & 7 & $(3.2)$ \\
13 & 171 & 26 & 3 & $(0.4)$ & 2 & $(0.9)$ \\
14 & 173 & 27 & 2 & $(0.3)$ & - & - \\
\hline
\end{tabular}

Table 2 ER $\beta$ allele 5 frequencies in AD cases and controls

\begin{tabular}{lccccccc}
\hline \multicolumn{6}{c}{$A D$} & \multicolumn{2}{c}{ Controls } \\
& $\mathrm{n}$ & $(\%)$ & $\mathrm{n}$ & $(\%)$ & $\mathrm{P}$ value & $\mathrm{OR}^{*}$ & $(95 \% \mathrm{Cl})^{*}$ \\
\hline Total & 54 & $(8.0)$ & 30 & $(13.6)$ & 0.014 & 0.55 & $(0.34-0.89)$ \\
Men & 20 & $(8.2)$ & 12 & $(16.2)$ & 0.045 & 0.46 & $(0.21-0.99)$ \\
Women & 34 & $(7.9)$ & 18 & $(12.3)$ & 0.11 & 0.61 & $(0.33-1.12)$ \\
\hline
\end{tabular}

*The $\operatorname{ER} \beta$ allele 5 was compared to the group of all other alleles.

replacement therapy among women in this study. Women treated with oestrogen that have $\operatorname{ER} \beta$ alleles other than the protective $\operatorname{ER} \beta$ allele 5 could therefore have escaped $\mathrm{AD}$ and entered the control group. However, the control group is quite small and allele 5 has a low frequency. This might have led to miss calculated frequencies, implying that there might be no differences between genders or even between $\mathrm{AD}$ patients and controls. It is often claimed that Bonferroni correction should be performed when doing an association study. However, it could be argued that this method is too stringent. As we have analysed 14 alleles we would need to reach a $P$ value less than 0.0036 to achieve a significant result with Bonferroni correction. Independent studies are therefore needed to confirm this association between $\operatorname{ER} \beta$ and AD. In favour of our hypothesis that allele 5 is implicated in the prevention of $\mathrm{AD}$ is that no $\mathrm{AD}$ patient homozygous for this allele was seen but three controls were found to be homozygous and there were three times more $\mathrm{AD}$ cases than controls in this study. The CA repeat investigated is intronic and it is therefore likely that the association found in this study is in linkage disequilibrium with a mutation elsewhere in the $\operatorname{ER} \beta$ gene or that the expression of $\operatorname{ER} \beta$ or its isoforms is changed. One example could be the $\operatorname{ER} \beta \mathrm{cx}$ isoform, where the C-terminus has been replaced by an alternative exon. It is thought to be a potential inhibitor of oestrogen action and has no ligand binding ability. ${ }^{23}$ An over expression of ER $\beta C x$ might therefore increase susceptibility to AD. In conclusion, our findings suggest the $\operatorname{ER} \beta$ allele 5 to be protective for AD. 
The next step in our investigations will be to examine the exons and the promoter region trying to find the underlying cause.

\section{Acknowledgements}

Bengt Winblad, Lena Lilius and Benita Engvall are thanked for supporting this study. The following foundations are acknowledged: Captain Artur Eriksson, Åke Wiberg, Claes Groschinsky, Lars Hierta, Osterman, Magnus Bergvall, Old Servants Foundation, the Alzheimer Foundation, King Gustaf V's and Queen Victoria's Foundation, Sandoz Foundation for Gerontological Research, the Swedish Medical Research Council (project no 10819).

\section{References}

1 Tsukamoto K, Inoue S, Husoi T, Orimo H, Emi M: Isolation and radiation hybrid mapping of dinucleotide repeat polymorphism at the human estrogen receptor $\beta$ locus. J Hum Genet 1998; 43: $73-74$.

2 Fratiglioni L, Viitanen M, von Strauss E, Tontodonati V, Herlitz B, Winblad B: Very old women at highest risk of dementia and Alzheimer's disease. Neurology 1997; 48: 132-138.

3 Jorm AF, Korten AE, Henderson VW: The prevalence of dementia: a quantitative integration of the literature. Acta Psychiatr Scand 1987; 76: 465 - 479.

4 Robinson D, Freidman L, Marcus R, Tinklenberg J, Yesavage J: Estrogen replacement therapy and memory in older women. JAGS 1994; 42: 919-922.

5 Baldereschi M, Di Carol A, Lepore V et al: Estrogen-replacement therapy and Alzheimer's disease in the Italian Longitudinal Study on Aging. Neurology 1998; 50: 996-1002.

6 Henderson VW, Paganini-Hill A, Emanuel CK, Dunn ME, Buckwalter JG: Estrogen replacement therapy in older women. Arch Neurol 1994; 51: 896-900.

7 Tang M-X, Jacobs D, Stern Y et al: Effect of estrogen during menopause on risk and age at onset of Alzheimer's disease. Lancet 1996; 348: $429-432$.

8 Mulnard RA, Cotman CW, Kawas C et al: Estrogen replacement therapy for treatment of mild to moderate Alzheimer's disease. JAMA 2000; 283: 1007-1015.

9 Jaffe AB, Toran-Allerand CD, Greengard P, Gandy SE: Estrogen regulates metabolism of Alzheimer amyloid $\beta$ precursor protein. J Biol Chem 1994; 269: 13065 - 13068.
10 Srivastava RAK, Srivastava N, Averna $\mathrm{M}$ et al: Estrogen upregulates apolipoprotein $\mathrm{E}$ (ApoE) gene expression by increasing ApoE mRNA in the translating pool via the estrogen receptor $\alpha$ mediated pathway. J Biol Chem 1997; 272: 33360-33366.

11 Ohkura T, Teshima Y, Isse $\mathrm{K}$ et al: Estrogen increases cerebrallar and cerebrallar blood flows in postmenopausal women. Menopause 1994; 2: $13-18$.

12 Birge SJ: The role of estrogen in the treatment of Alzheimer's disease. Neurology 1997; 48: S36-S41.

13 Isoe K, Ji Y, Urakami K, Adachi Y, Nakashima K: Genetic association of estrogen receptor gene polymorphism with Alzheimer's disease. Alzheimer's Res 1997; 3: 195-197.

14 Mattila KM, Axelman K, Rinne JO et al. Interaction between estrogen receptor 1 and the $\varepsilon 4$ allele of apolipoprotein $\mathrm{E}$ increases the risk of familial Alzheimer's disease. Neurosci Lett 2000; 282: $45-48$.

15 Maruyama H, Toji H, Harrington CR et al: Lack of an association of estrogen receptor $\alpha$ gene polymorphisms and transcriptional activity with Alzheimer disease. Arch Neurol 2000; 57: 236-240.

16 Kuiper GGJM, Enmark E, Pelto-Huikko M, Nilsson S, Gustavsson $\mathrm{J}$-A: Cloning of a novel estrogen receptor expressed in rat prostate and ovary. Proc Natl Acad Sci 1996; 93: 5925-5930.

17 Mosselman S, Polman J, Dijkema R: ER $\beta$ : identification and characterisation of a novel human estrogen receptor. FEBS Lett 1996; 392: $49-53$

18 Enmark E, Pelto-Huikko M, Grandien K et al: Human estrogen receptor $\beta$-gene structure, chromosomal localisation, and expression pattern. J Clin Endocrinol Metab 1997; 82: 4258 4265 .

19 Shughrue PJ, Lane MV, Merchenthaler I: Comparative distribution of estrogen receptor $\alpha$ and $-\beta$ mRNA in the rat central nervous system. J Comp Neurol 1997; 388: 507-525.

20 Axelman K, Basun H, Lannfelt L: Apolipoprotein E and $\alpha 1$ antichymotrypsin genotypes and age of onset in familial Alzheimer's disease. Dement Geriatr Cogn Disord 1999; 10: $1-5$.

21 American Psychiatric Association: Diagnostic and statistical manual of mental disorders. APA. Washington, 1994, Fourth edition

22 Blomberg M, Jensen M, Basun H, Lannfelt L, Wahlund L-O Cerebrospinal fluid Tau levels increase with age in healthy individuals. Dement Geriatr Cogn Disord 2001; 12: 127-132.

23 Ogawa S, Inoue S, Watanabwe T et al: Molecular cloning and characterization of human estrogen receptor $\beta c x$ : a potential inhibitor of estrogen action in human. Nucleic Acids Res 1998; 26: $3505-3512$. 